\title{
The Stem of Meaningful Learning
}

\author{
Bassem Kandil ${ }^{1}$ \\ ${ }^{1}$ Assistant Professor, Faculty of Educational Sciences, Saint Joseph University of Beirut, Lebanon
}

\begin{tabular}{|c|c|}
\hline Artic & Abstract \\
\hline Articl & xamine the effects of integrated \\
\hline Rec & Science, Technology, Engineering, and Mathematics (STEM) education on \\
\hline Rer & demic achievement in the science classroom. \\
\hline & $\begin{array}{l}\text { Methodology: This study is a quasi-experimental using non-equivalent } \\
\text { control group pretest-posttest design. Fifty-one Grade } 8 \text { students, taught by }\end{array}$ \\
\hline$\overline{\text { Key }}$ & the same teacher, constituted the participants of this study. The study \\
\hline STE & consisted of an experimental group that followed a STEM approach to \\
\hline ea & $\begin{array}{l}\text { education and a control group that was taught the usual way. } \\
\text { Results: The findings showed an encouraging improvement in the science }\end{array}$ \\
\hline Achie & achievement of the experimental group as compared to that of the control \\
\hline Paper Type : & $\begin{array}{l}\text { one. Students belonging to the experimental group demonstrated conceptual } \\
\text { understanding of the topics covered by the assigned problems. }\end{array}$ \\
\hline Research Articl & $\begin{array}{l}\text { Practical Implications: An initial implication is that STEM education is a } \\
\text { promising approach that, if properly implemented, facilitates meaningful }\end{array}$ \\
\hline Correspondi & $\begin{array}{l}\text { learning. } \\
\text { Originality/Value: } \text { The problem/project-based way of teaching and learning }\end{array}$ \\
\hline $\begin{array}{l}\text { Bassem Kandil } \\
\text { Email: } \\
\text { bassem.kandil1@usj.edu.1b }\end{array}$ & $\begin{array}{l}\text { allows students to appreciate the relevance of their school work to their own } \\
\text { lives and the world around them. Besides the positive impact of STEM } \\
\text { education on science achievement, the findings of this study revealed that a } \\
\text { STEM approach is a promising approach in terms of developing conceptual } \\
\text { understanding and promoting transfer of learning. }\end{array}$ \\
\hline
\end{tabular}

1. Introduction

Lebanon has been suffering from poor performance in the TIMSS international exams since 2003. TIMSS, Trends in International Mathematics and Science Study, is an international assessment of mathematics and science at the fourth and eighth-grade levels. "TIMSS assessment covers a range of thinking skills, including students' abilities to apply what they have learned, solve problems, and use analysis and logical thinking to reason through situations; two-thirds of the items require students to use applying and reasoning skills" (Mullis \& Martin, 2017). In 2019, Lebanon ranked among the worst countries in Math and Science. In particular, the average science score of the eighth-grade students who participated in the TIMSS 2019 was 377; which is below the international CenterPoint (500) and the secondlowest score just before South Africa, the country with the lowest score of 370 (Mullis, et al., 2020).

Though many factors can be attributed to the reasons for such poor performance, the fact remains that our Grade 8 students couldn't correctly solve problems that require conceptual understanding or higher-order thinking. In the most optimistic scenario, there is an apparent 
lack of transfer of learning. In an attempt to address this issue, the researcher, through this study, decided to examine the impact or the effects of STEM education on science achievement and conceptual understanding.

Many definitions have been assigned to STEM education; however, the researcher chose to adopt the following two definitions of STEM: Vasquez et al. (2013) defined STEM education "as a learning approach which eliminates the usual barriers between science, technology, engineering, and mathematics and combines them with real-life learning experiences". O'Neill et al. (2012) defined STEM education as a "transdisciplinary approach that utilizes a project-based learning to address real-world issues".

Students following a STEM approach "demonstrated greater levels of engagement, willingness, and ability to engage in critical thinking and problem-solving and overall higher academic achievement as marked by subject test scores and end-of-term grades" (O'Neill et al., 2012). In addition, a study by Ozkan (2020) revealed that a STEAM (Science, Technology, Engineering, Arts, Mathematics) approach to education enhanced the conceptual understanding of the science topics that a sample of middle-grade students was involved in.

According to Mustafa et al. (2016), "STEM education develops problem-solving skills, promotes student-centered learning, and cultivates higher-order thinking skills". Based on the examination of various studies about STEM education, it turns out that the most prominent strategy to implement STEM education is through a project-based learning approach (Mustafa et al., 2016).

As for the transfer of learning, Mayer and Wittrock (1996) defined it as: "transfer is the ability to use what was learned to solve new problems or answer new questions". In addition, transfer is an indicator of meaningful learning. According to Mayer (2002), "meaningful learning occurs when students build the knowledge and cognitive processes needed for successful problem solving". So, students are motivated by STEM education which in turn provides excellent learning opportunities for students to practice transfer of learning and ultimately acquire meaningful learning.

The purpose of this study is to examine the impact of STEM education on a group of middle-grade students in an attempt to uncover the effects of such an approach in the science classroom. In particular, this study is guided by the following research questions:

1) What is the impact of a STEM unit on students' achievement in the science classroom?

2) Does a STEM approach enhance conceptual understanding in the science classroom?

The conceptual framework of this study is underpinned by various concepts derived from the Situated Learning Theory (Lave \& Wenger, 1991), Revised Bloom's Taxonomy (Anderson, et al., 2001), Socio-cultural theory of Cognitive Development (Vygotsky, 1978) and Learning by Doing (Dewey, 1938). Meaningful learning is thus constructed through the following process: 


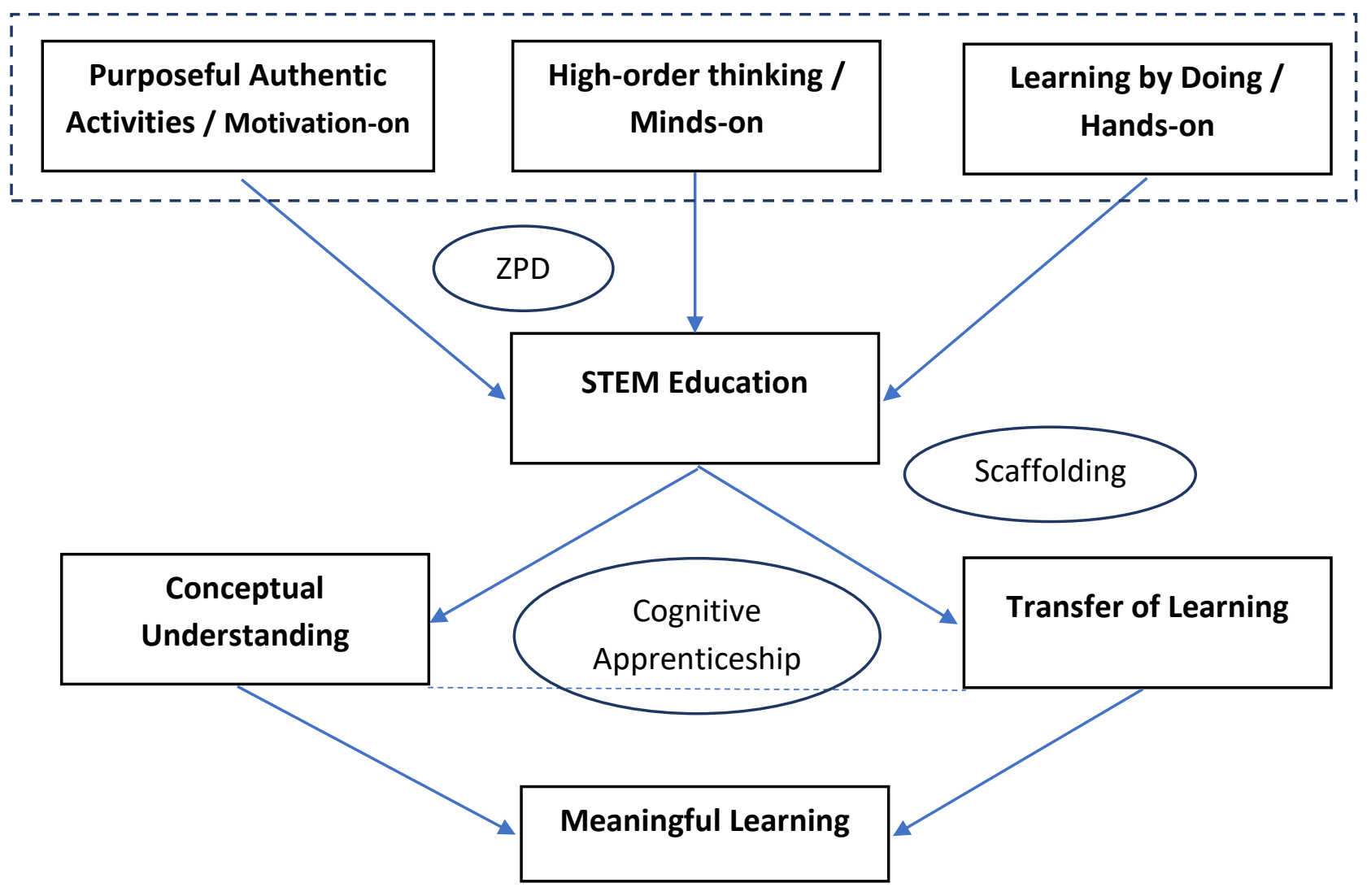

Figure 1: Conceptual Framework

The significance of this study emanates from the fact that the Lebanese educational system lacks practices that positively affect the achievement or the performance of its students. And the researcher hopes that the findings of this study will encourage or motivate educators, curriculum designers, and policymakers to systematically integrate active teaching methods such as STEM education into the relevant subject matters of the Lebanese curricula.

\section{Methodology and Procedures}

This research is quasi-experimental research using a non-equivalent control group pretestposttest design. It aims to measure the relationship between STEM education and Science achievement.

\section{Participants and Setting}

A total of fifty-one Grade 8 students from a private school, that is located in Beirut, constituted the sample or the participants of this study. The experimental group were students of section A of the eighth grade in that school and were taught using a STEM approach; the control group was the students of section B of the same grade level, and they were taught the same unit using the usual way of instruction. In other words, the control group was taught 
using a teacher-centered approach in which the lecture was the main mode of instruction. The demographics of the participants are illustrated in Table 1.

Table 1: Demographics of the participants

\begin{tabular}{|l|c|c|}
\hline & \multicolumn{2}{|c|}{ Group } \\
\hline \multicolumn{1}{|c|}{$\mathrm{n}$} & Experimental (G8A) & Control (G8B) \\
\hline Male & 12 & 12 \\
\hline Female & 14 & 13 \\
\hline \multicolumn{1}{|c|}{ Total } & 26 & 25 \\
\hline
\end{tabular}

Source: Authors

\section{Procedure}

Both groups were instructed by the same teacher who took intensive training about STEM education prior to the implementation of this study. The unit of instruction was about Motion and Energy. The two groups or sections used the same science textbook which is from an international publisher. The main topics covered by the unit along with the corresponding STEM activities can be found in Table 2.

Table 2: The details of the Science Unit

\begin{tabular}{|c|l|l|}
\hline Unit & \multicolumn{1}{|c|}{ Motion and Energy } & \multicolumn{1}{c|}{ STEM Activities } \\
\hline Lesson 1 & Motion (Newton's Laws of Motion) & $\begin{array}{l}\text { Develop and practice with a } \\
\text { balloon-powered car. }\end{array}$ \\
\hline Lesson 2 & Velocity and Acceleration & \\
\hline Lesson 3 & Kinetic and Potential Energy & \\
\hline
\end{tabular}

Source: Authors

The unit of instruction took around fifteen teaching sessions over a period of two months. The broad tasks that were done during the various sessions can be found in Table 3. It is worth mentioning that section A allocated more time to inquiry and exploration whereas section B allocated more time to practice and worksheets.

Table 3: Tasks done by each group

\begin{tabular}{|l|l|}
\hline \multicolumn{1}{|c|}{ Section A } & \multicolumn{1}{|c|}{ Section B } \\
\hline $\begin{array}{l}\text { Engage phase: Design and build a balloon- } \\
\text { powered car that travel as far and as fast as } \\
\text { possible. } \\
\begin{array}{l}\text { Exploration phase: } \\
\text { Troubleshooting / Guided Discussions }\end{array}\end{array}$ & \multirow{2}{*}{ Explanation phase: PowerPoint presentations. } \\
\cline { 1 - 2 } Explanation phase & Short Quizzes \\
\hline Applications & Evaluation phase: Summative Assessment \\
\hline Evaluation phase: Summative Assessment &
\end{tabular}

Source: Authors

\section{Baseline Assessment}


Students' averages from the previous year (Grade 7) were examined just to make sure that the two Grade 8 sections don't differ significantly in terms of Science achievement. In addition, a 9-question pretest was given to the two sections to verify an equal baseline level.

\section{Intervention Assessment}

At the end of the unit of instruction, both groups took the same 15-question posttest. The posttest was compiled by the teacher based on the adopted science curriculum and it was also reviewed by the researcher. The selected questions were conceptual problems that require deep understanding for students to answer or solve. A t-test was used to compare the means of the two groups to examine the relationship between STEM education and achievement scores in science.

\section{Teacher Preparation}

Before the initiation of the intervention phase, the concerned teacher attended training about STEM education. The training journey took four weeks (with an average of six hours per week) and covered the design and practical aspects of STEM education. The training was in the form of a workshop that simulated much of what should happen in typical classroom instruction. In addition, the STEM activities were co-designed by the teacher and the researcher based on the adopted science textbook and relevant online resources.

\section{Results and Discussion}

Besides the results about science achievement and conceptual understanding, the researcher uncovered an interesting aspect regarding the journey of the concerned teacher when he was inquiring about the level of preparedness.

\section{The Training}

The researcher had a short interview with the teacher about her training journey and she replied as follows:

"The journey started with uncertainty as to what is STEM education and what is the best way for such an approach. At the beginning of the training, the following questions popped into my head:

a) What is STEM for real? Is it an approach, a curriculum, a set of activities ...? b) Should the four disciplines be integrated so that the activity is considered to be a STEM one? c) Is it project-based? d) Should we always use technology? e) What about Engineering? f) Should our students work individually or in groups? g) How are we going to assess our students?

I was a little bit confused in the beginning; however, as time passes, I realized that STEM is more than a mere integration of the four disciplines of Science, Technology, Engineering and Mathematics. STEM is inquiry-based and project-based in a realworld context. Much of the learning is done by discovery. Students are active participants in building new content knowledge; our primary role is to guide them through and to provoke thinking..." 


\section{Establishing Baseline}

Besides examining the science averages from the previous year for both sections, which were too close to each other; the research activity started with a pretest that was used to verify that both groups have almost the same achievement level before the initiation of the intervention. The experimental group's pretest average was 10.15; the control group's pretest average was 9.36 which is very close to that of the experimental group as indicated in Table 4.

Table 4: Pretest scores for both groups

\begin{tabular}{|c|c|}
\hline Group & Pretest Mean / 20 \\
\hline Experimental & 10.15 \\
\hline Control & 9.36 \\
\hline
\end{tabular}

Source: Authors

\section{Findings related to the first research question}

The first research question was about the effect of a STEM approach to teaching on the achievement scores in science. As the means of scores in Table 5 indicate, students of the experimental group (Section A), who followed a STEM approach, scored (14.73) higher than those in the control group (12.04).

Table 5: Posttest scores for both groups

\begin{tabular}{|c|c|c|c|c|}
\hline Section & N & Mean & Std. Deviation & Std. Error Mean \\
\hline Posttest A & 26 & 14.73 & 1.779 & 0.349 \\
\hline Posttest B & 25 & 12.04 & 1.947 & 0.389 \\
\hline
\end{tabular}

Source: Authors

In addition, the T-test presented in Table 6 below indicates that the difference in the means of the posttests between the two groups was significant, $t(49)=5.156 ; p=0.000$.

Table 6: Independent samples t-test

\begin{tabular}{|c|c|c|c|c|c|c|}
\hline Posttest & $\mathrm{F}$ & Sig. & $\mathrm{t}$ & $\mathrm{df}$ & Sig(2-tailed) & Mean Difference \\
\hline $\begin{array}{c}\text { Equal } \\
\text { variances } \\
\text { assumed }\end{array}$ & 0.187 & 0.667 & 5.156 & 49 & 0.000 & 2.691 \\
\hline $\begin{array}{c}\text { Equal } \\
\text { variances not } \\
\text { assumed }\end{array}$ & & 5.147 & 48.188 & 0.000 & 2.691 \\
\hline
\end{tabular}

Source: Authors

The findings above clearly indicates that a STEM approach to teaching improves the achievement scores in science. 


\section{Findings related to the second research question}

The second research question aims to examine whether a STEM approach to instruction enhances the conceptual understanding of students in the science classroom. Since the questions of the posttest exam were designed in a way that requires relatively deep conceptual understanding to be able to answer them correctly, the scores of the experimental group, as shown in Table 7 below, clearly indicate that the performance of the participants in the experimental group was enhanced and they were able to answer most of the assigned questions.

Table 7: Paired Samples Statistics

\begin{tabular}{|c|c|c|c|c|}
\hline $\begin{array}{c}\text { Experimental } \\
\text { Group }\end{array}$ & Mean & $\mathrm{N}$ & Std. Deviation & Std. Error Mean \\
\hline Pretest & 10.15 & 26 & 2.378 & 0.466 \\
\hline Posttest & 14.73 & 26 & 1.779 & 0.349 \\
\hline
\end{tabular}

Source: Authors

In addition, the mean difference between the pretest and the posttest of the experimental group was 4.577; and this difference was significant $(\mathrm{p}<0.01)$ as shown in Table 8.

Table 8 Paired Samples Test

\begin{tabular}{|c|c|c|c|c|}
\hline Pair1 & Mean(difference) & $\mathrm{t}$ & df & Sig.(P) \\
\hline Posttest-Pretest & 4.577 & 18.84 & 25 & 0.000 \\
\hline
\end{tabular}

Thus, we can conclude that the participants in the experimental group have acquired, to a great extent, a conceptual understanding of the topics covered by the posttest. Furthermore, Figure 2 indicates that a STEM education approach enhanced students' achievement in science within and among the groups.

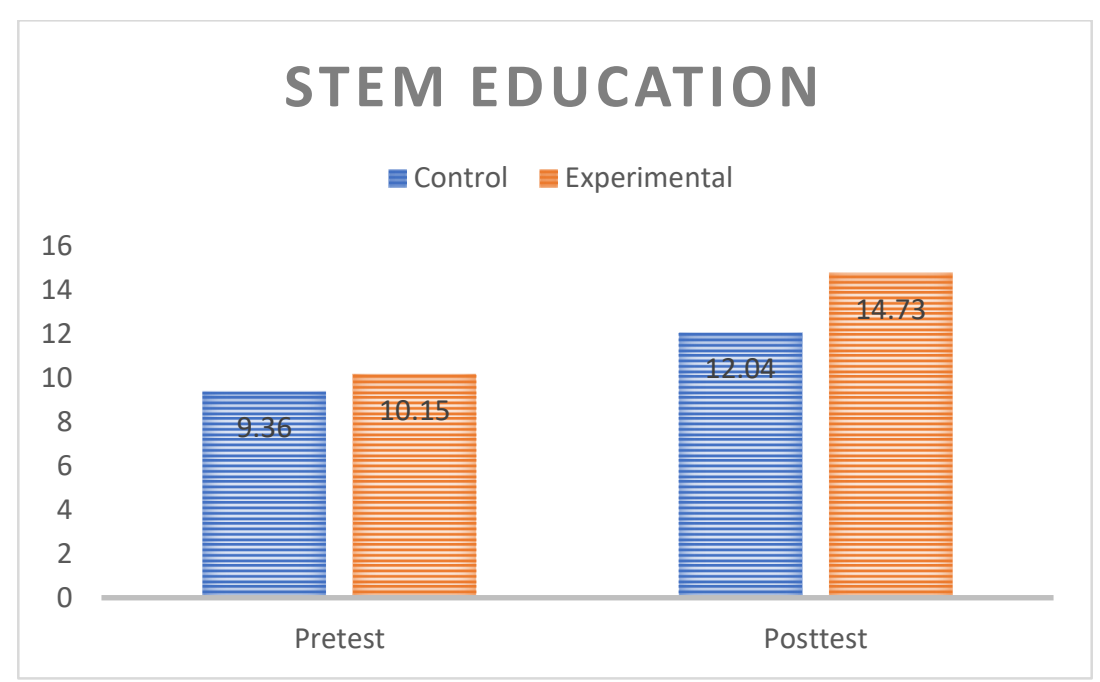

Figure 2: Improvements within and among groups 
The findings of this study come in accordance with the positive spectrum of the effects of STEM education. Yilidrim (2016), in his meta-synthesis study about research on STEM education, reported that fifty percent of the studies that he examined about the effects of STEM education on academic success or academic knowledge showed a positive effect on students' academic success or academic knowledge. Wade and Shepherd (2016) reported significant improvement in math and achievement scores for secondary students who were taught through a STEM approach as compared to those who received traditional instruction. Wendell and Rogers (2013) stated that a curriculum unit based on engineering design improved the students' science knowledge. In addition, Olivarez (2012) concluded that a STEM-based program enhances success in science, math, and reading.

However, for such an improvement to take place, educators should perceive STEM education as a journey and not just an event or a fragmented set of activities. It is a well-planned journey with milestones that resonate with the various cognitive levels of the revised Bloom's taxonomy. What the researcher noticed during the early implementation phase of this research study is that students, belonging to the experimental group, faced some difficulties to come up, on their own, with a fully functional product or solution; that is, they initially faced difficulties thinking at the highest level of Bloom's taxonomy--the Create level. Though not foreseen, it wasn't surprising because most of the Lebanese students are usually taught at the three lower levels of the taxonomy; and through this study, they were prompted to operate at the highest level. That's why the researcher advised the teacher to scaffold learning by what he would like to name or call Pre-STEM activities; activities that bridge the thinking gap between the lowest levels of Bloom's taxonomy and the highest level aimed. This opens the door for a qualitative study that attempts to identify the proper implementations of a STEM education or approach.

\section{Conclusion and Suggestion}

If students lack conceptual understanding in science, they will fail to transfer learning to other relevant situations especially those that require problem-solving or higher-order thinking. TIMSS exams are no exception. That's why aiming for conceptual understanding and teaching for transfer are the cornerstones of any educational reform related to students' achievement and performance. STEM is about using math, science, and technology to solve or address real-world challenges or problems. This applied, problem/project-based way of teaching and learning allows students to appreciate the relevance of their school work to their own lives and the world around them. Besides the positive impact of STEM education on science achievement, the findings of this study revealed that a STEM approach is a promising approach in terms of developing conceptual understanding and promoting transfer of learning. A transfer that constitutes the stem of meaningful learning.

\section{Conflict of Interest}

The author declares no conflict of interest. 


\section{Funding}

The study was not funded by any institution/ university.

\section{References}

Anderson, L. W., Krathwohl, D. R., \& Bloom, B. S. (2001). A taxonomy for learning, teaching, and assessing: A revision of Bloom's Taxonomy of educational objectives (Complete ed.). Longman.

Dewey, J. (1938). Experience and education. New York: Simon \& Schuster.

Lave, J., \& Wenger, E. (1991). Situated learning: Legitimate peripheral participation. Cambridge University Press.

Mayer, R.E. (2002). Teaching for meaningful learning. Upper Saddle River, NJ: PrenticeHall

Mayer, R.E., \& Wittrock, M.C. (1996). Problem-solving transfer. In D.C. Berliner \& R.C. Calfee (Eds.), Handbook of educational psychology (pp. 47-62). New York: Macmillan

Mullis, I. V. S., \& Martin, M. O. (Eds.). (2017). TIMSS 2019 Assessment Frameworks. Retrieved from Boston College, TIMSS \& PIRLS International Study Center website: http://timssandpirls.bc.edu/timss2019/frameworks/

Mullis, I. V. S., Martin, M. O., Foy, P., Kelly, D. L., \& Fishbein, B. (2020). TIMSS 2019International Results in Mathematics and Science. Retrieved from Boston College, TIMSS \& PIRLS International Study Center website: https://timssandpirls.bc.edu/timss2019/international-results/

Mustafa, N. A. Ismail, Z. Tasir, Z. \& Said, M.N.H.M. (2016). A Meta-Analysis on Effective Strategies for Integrated STEM Education. Advanced Science Letters, Volume 12, pp.1936-6612.

Olivarez, N. (2012). The impact of a STEM program on academic achievement of eight grade students in a south texas middle school. Doctoral Dissertation, Texas A \& M University, Texas.

O’Neill, T., Yamagata, L., Yamagata, J., \& Togioka, S. (2012). Teaching STEM means teacher learning. Phi Delta Kappan, 94(1), 36-40.

Ozkan, G. \& Topsakal, U. (2020). Investigating the effectiveness of STEAM education on students' conceptual understanding of force and energy topics. Research in Science \& Technological Education. DOI: 10.1080/02635143.2020.1769586 
Vasquez, J., Sneider, C., \& Comer, M. (2013). STEM Lesson Essentials. New Hampshire: Heinemann.

Vygotsky, L. S. (1978). Mind in society: The development of higher psychological processes Cambridge, Mass.: Harvard University Press.

Wade- Shepherd, A. A. (2016). The effect of middle school STEM curriculum on science and math achievement scores. Doctoral Dissertation, Union University, Tennessee.

Wendell, K. B. \& Rogers, C. (2013). Engineering design-based science, science content performance, and science attitudes in elementary school. Journal of Engineering Education, 102(4), 513- 540. https://doi.org/10.1002/jee.20026

Yildirım, B. (2016). An Analyses and Meta-Synthesis of Research on STEM Education. Journal of Education and Practice, 7(34), 1735-2222. 